\title{
Paying Politicians: Theory and Evidence
}

\author{
Timothy Besley ${ }^{*}$ \\ London School of Economics
}

\begin{abstract}
This paper looks at the theory behind the idea that paying politicians better will improve their performance. The paper lays out a political agency model with adverse selection and moral hazard where politicians are subject to two-period term limits. This model provides a number of predictions about how the pay of politicians affects agency problems. We also consider what happens when the pool of politicians is endogenous. The main ideas in the model are confronted with data on U.S. Governors.
\end{abstract}

${ }^{*}$ This paper was first given as the Joseph Schumpeter Lecture at the 18th Congress of the European Economics Association in Stockholm. I am grateful to Robin Burgess, Rohini Pande, Ray Fisman, Sanjay Jain, Rocco Macchiavello, Torsten Persson, Michael Smart, and Daniel Sturm for useful discussion and comments on a earlier draft. Daniel Sturm and Ray Fisman were also kind in offering me access to their data. Marit Rehavi and Silvia Pezzini provided excellent research assisitance.

${ }^{\dagger}$ e-mail address: t.besley@lse.ac.uk 


\section{Introduction}

While a great deal of attention has been paid to the remuneration of chief executives in the private sector, comparatively little has been written about political chief executives such as Prime Ministers and Presidents. But pay setting for politicians is an important issue and the pros and cons of wage increases are often hotly debated. This lecture focuses on two questions - (i) What is the effect (theoretically speaking) of changing the remuneration paid to politicians? (ii) Is there any evidence that such remuneration affects the behavior of politicians or who chooses to run for office?

To set the scene, it is interesting to look at a small selective sample of political chief executives. To this end, Table 1 gives some figures for four countries - the U.K., U.S.A., France and Sweden. The U.S. President is the best paid at around $\$ 400,000$ with the British Prime minister coming second at $\$ 270,000$. The worst paid is the French President at $\$ 70,000$ - worse than a starting assistant professor in Economics in a U.S. University! Relative to income per capita, the ranking is also preserved. The U.K. and U.S.A. both pay around ten times national income per capita, while France pays only three times. However, these jobs carry very different responsibilities. The third row standardizes the salaries of these chief executives relative to the size of the government budget. On this basis, the U.S. President is actually the worst paid with Sweden now topping the league table followed by the U.K.. The fourth row standardizes this by population size. The Swedish prime minister is now comfortable the best paid, with the U.K. second. France and the U.S. look fairly similar on this basis. These numbers are only illustrative, but they serve to focus our mind on the issues at hand.

Officials may also have very different domains of responsibility, terms 
and methods of accountability. Any serious comparison of wages would have standardize across payments from different sources and job description. It is largely for this reason that the empirical analysis in this lecture focuses on a very specific group - Governors in the U.S..

A data set for U.S. Governors provides a more comparable source since they perform largely similar tasks in a common institutional setting. The Governor of California is paid $\$ 165,000$ to preside over a budget of $\$ 150$ billion (including Federal funds) with a population of roughly 34 million, while the Governor of Montana is paid around $\$ 84,000$ to preside over a budget of $\$ 3$ billion and a population of just 900,000. The average pay of a Governor in 2000 was $\$ 105,000$. To put this in perspective, the median CEO compensation package for the Mercer/Wall Street Journal Survey of the 350 biggest publicly held companies is around $\$ 6.1$ million. $^{1}$

The main justification for the high level of chief executive compensation levels is that it generates good incentives and enhances corporate performance. This can be thought of in a standard principal agent model where it is difficult to monitor the actions of managers - monetary incentives are needed to diminish any conflict of interest between managers and shareholders. The efficacy of monetary incentives in political settings is far from clear. Discussions have frequently adopted a view based on the notion that political service is a calling and that money is a distraction. This is nicely illustrated by the following quote from an article published in The Idaho Statesman of 1945 complaining about the behavior of the incumbent Senator:

"The best of our public officials don't seek their positions for

\footnotetext{
${ }^{1}$ See http://www.mercerhr.com/knowledgecenter/reportsummary.jhtml/dynamic/idContent/1089750
} 
the money. There are other and infinitely greater rewards. For a senator who can win it, there is the respect of his ablest colleagues, and that is something no money-chaser has ever had. There is his own respect to win and keep, and his conscience to live with, while devoting himself faithfully to the welfare of his country. And after his long service is over there is the monument to himself in the memory and the gratitude of the people he served. If such deep and abiding gratifications don't make your salary seem rather incidental, then you don't belong there, and the people of Idaho will be happy to relieve you of the job in 1950." ${ }^{2}$

This view belongs to a respectable tradition that views the political process as a means of getting the right people to make policy decisions. In this vein, the great American political scientist, V.O. Key argued that:

"(t)he nature of the workings of government depends ultimately on the men who run it. The men we elect to office and the circumstances we create that affect their work determine the nature of popular government. Let there be emphasis on those we elect to office. Legislators, governors and other such elective functionaries ultimately fix the basic tone and character of state government." V.O. Key (1956 page 10).

This sentiment should also make sense to economists. Thus, Lazear and Rosen (1980) note that:

\footnotetext{
${ }^{2}$ From "Salaries of Politicians by Vardis Fisher, The Idaho Statesman, January 16, 1945 available at http://library.boisestate.edu/special/fishercolumn/number8.htm.
} 
"Public service has always been viewed as a social obligation, somehow different from other careers, and the responsibilities, duties, and personal conduct of public officials has been regarded somewhat differently from those of people holding positions in the private economy." Lazear and Rosen (1980 page 101).

But how exactly do such sentiments factor into political agency and the role of elections in improving the quality of policy? How should they affect wage setting policies? These are the issues that will concern me here. While not seeking to re-instate the benevolent government paradigm entirely, the approach that I will take will put greater weight on the importance of selection. Following Key and others, I take it as a possibility that some individuals are more publicly spirited than others and that one role of good governance is to get the right people (persons of character to use a phrase favoured by James Maddison) making social decisions. This is not to argue that standard self-interest concerns are not important - problems such as bribery and corruption which infect many aspects of public life are grounded in the self-interest motive in politics.

The possibility of benevolence is somewhat at odds with the dominant traditions in political economy emanating from Chicago and Virginia. They are founded on applying standard economic reasoning to political life - this includes the presumption that actors are narrowly selfinterested. Thus, in his characterization of the Public Choice approach, Buchanan (1989) takes it as given that "Individuals must be modeled as seeking to further their own narrow-self interest, narrowly defined, in terms of measured net wealth position, as predicted or expected." (Buchanan (1989, page 20)). He also suggests that "(t)o improve pol- 
itics, it is necessary to improve or reform rules, the framework within which the game of politics is played. There is no suggestion that improvement lies in the selection of morally superior agents who will use their powers in some "public interest" (Buchanan (1989, page 18)).

In political life, perhaps the most basic incentive comes from the need to be re-elected - politicians who do not do what voters like are removed from office. Barro (1973) suggested an approach to incentives in politics where elections are used to discipline incumbents. ${ }^{3}$ This has spawned a significant interest in political agency problems. Since wages affect the value of holding office, then using the standard logic of efficiency wages, it should be easier to inculcate policy in the voters' interest when wages are high. ${ }^{4}$

The approach that I take here allows for unobserved heterogeneity in the types of politicians (adverse selection) as well as unobserved actions (moral hazard). We are then able to consider the role of wages in sorting politicians as well as their role in achieving discipline in the standard way. I construct an agency model with two main features. First, time is infinite and there are successive generations of politicians each of whom can serve at most two terms. Second, the politicians can choose to enter politics and their decision to do so depends upon their outside option and their payoffs in political office. The main innovation proposed here is to embed the agency model in a framework where the pool of politicians is endogenous.

This lecture will look primarily at theory. However, it also considers evidence from a very particular source - U.S. Governors. The standard political agency model with a single agent directly accountable

\footnotetext{
${ }^{3}$ See also Ferejohn (1986).

${ }^{4}$ This argument was put forward for public sector employees in general in Becker and Stigler (1974).
} 
to the voters has an air of reasonableness about it in this case. Moreover, Besley and Case (1995a,b) has suggested that some of the model's predictions appear consistent with some aspects of policy making for taxes and spending. U.S. Governors also afford us a reasonable amount of data. We have information about wages and political behavior of Governors for over forty years.

The remainder of the lecture is organized as follows. In the next section, I discuss some background issues and the existing literature on politicians' pay. In the following section, I set out a simple theoretical model. In the first instance, the pool of politicians is taken as fixed. Subsequently, I generalize the model to allow for selection into politics. We discuss a number of extensions in section four. In section five, the ideas in the model are confronted with data on U.S. Governors. Section five concludes.

\section{Background}

The kinds of contracts that regulate political life are clearly incomplete in a variety of ways. Politicians tend to be regulated by career concerns ${ }^{5}$ (broadly defined) rather than by formal incentive contracts. The main incentive mechanism is re-election. This gives the voters an opportunity to reward or punish a politician for his poor performance while in office. One striking feature of political compensation is that we do not observe schemes that pay for performance, so-called high powered incentives. However, there is no obvious reason why constitutional arrangements could not be found that injected some form of monetary incentive into political life. For example, politicians' pay could be uprated according to the number of times that they have been re-elected. In fact, we do

\footnotetext{
${ }^{5}$ See Holmstrom(1999) for the seminal analysis of career concerns.
} 
sometimes see this happening through pension arrangements. Pay could also be tied to certain key observable outcomes such as tax increases, budget deficits and efficiency measures. In fact, the latter are becoming more popular in public bureaucracies. Nonetheless, high powered incentive schemes seem non-existent in political life.

There would clearly be practical difficulties in instituting formal constitutional arrangements for incentive pay. It might be difficult to articulate many objectives such as "doing what voters want" - it is hard to discern which voters and which issues would be granted primary importance in this context. Even with more objective indicators, there would be difficulties in defining these in precise and non-manipulable ways. Indeed, the experience with target setting in public bureaucracies has shown the difficulty of creating clear and credible performance measures that cannot easily be gamed.

It is also clear that politicians are charged with a wide variety of tasks which compete for their attention. The most measurable of these tasks are not necessarily the most important. Thus, standard setting in easily quantifiable tasks would risk diverting attention from the most socially valuable allocation of time. This is the familiar multi-tasking problem analyzed in Holmstrom and Milgrom (1991).

Since politicians are serving many constituencies, there is also the danger that different components of their remuneration could be set by different groups. Some groups would wish to see greater attention paid to environmental issues while others might see trade or macro-economics as a paramount concern. If there were some way of bringing all of the principals together and coordinating their actions, this would create a coherent set of incentives. But if there are multiple competing principals, then they could end up competing with one another to get their 
cause attended to. ${ }^{6}$ In fact, thinking about the issue this way, shows how public transfers to politicians in the form of explicit monetary bonuses might actually increase the supply of private transfers from lobbying groups who seek to undo the effect of public sector incentives. The overall result would likely be flatter incentives.

A final reason for flat incentive schemes could also be that politics selects motivated agents who are willing to supply effort without the need for incentive payments. This is the theme of Besley and Ghatak (2003) who apply the idea to bureaucratic incentives. ${ }^{7}$ If individuals sort into tasks according to the extent of their motivation, then the need for explicit incentives is attenuated.

But how well are politicians paid relative to other occupations? It is remarkably difficult to get a coherent picture. First, compensation does not only come in the form of direct pay; it includes "allowances" such as housing, transportation and pension rights. As we noted above, the data on U.S. Governors suggested a wide variation in pay rates. Second, job descriptions vary enormously. For example, in accordance with the Texas Constitution, the legislature meets in a regular legislative session in Austin once every two years.

When deciding how politicians should be paid, one route would be to link public and private sector pay explicitly, for example by finding some kind of comparable private sector job as a benchmark for that in the public sector. However, as Lazear and Rosen (1980) note, the principle of comparability has only limited relevance. How for example, would one find a suitable comparator for a U.S. Governor or a Prime Minister. Public-private wage differentials reinforce the idea that monetary factors

\footnotetext{
${ }^{6}$ For a discussion of the multiple principals problem in politics, see Dixit (1996).

${ }^{7}$ See Frey (1997) for an insightful discussion of motivation in economics emphasising the importance of intrinsic motivation.
} 
play a fairly small role in the decision to enter government service. Also, viewing the problem as purely a comparability issue neglects the more fundamental questions of selection and incentives which ought to ground the problem.

In principle there are two sets of issues to be studied - (i) what determines politicians' wages? and (ii) do they affect the behavior of politicians or change the composition of the pool of potential politicians? This paper will look mainly at the second of these.

A sizeable political science literature on politicians' pay devotes relatively more attention to the sorting effects of pay. For example Squire (1992) considers the argument that legislative diversity will increase as it is possible for larger array of people to run for office. He studies the issue at the level of state legislatures in the U.S. to see whether it reduces the "white-male lawyer" bias in political representation. He finds that higher wages (and greater professionalization in general) are correlated with representation of minorities. Sollars (1994) looks at the determination of legislative pay rather than its consequences. He constructs comparable numbers of legislator pay across states which factor in the differences in time commitment and expense allowances. His analysis gives a sense of the wide diversity in the remuneration. For example, for the 1988-89, a legislator in California was paid around $\$ 41,000$ compared to around $\$ 9,000$ in Arkansas and $\$ 4,200$ in Utah. Thus, the differences in salaries are not small.

Incentive effects of pay have received much less attention. However, Coates (1999) looks at whether there is a link between state economic performance and the pay of politicians. He finds a positive correlation between salaries and the quantity of legislation passed, but little vari- 
ation with economic growth at the state level. ${ }^{8}$ Di Tella and Fisman (2001) look at determinants of Gubernatorial wages in the U.S. To this end, they assemble a series on wages of U.S. governors. They find that favorable state economic conditions (particularly income per capita) are positively correlated with wage increases among governors.

The problem of candidate selection can fruitfully be addressed using the citizen candidate framework developed by Osborne and Slivinsky (1996) and Besley and Coate (1997). A number of papers have considered the importance of electoral rewards using the approach. Messner and Polborn (2001) consider a pure public good provision game in which citizens choose to enter and consider how changing the wage on offer to politicians can induce greater entry by competent candidates. Poutvarra and Takalo (2003) develop a model in which the value of holding office impinges on candidate quality via its affect on election campaigns. They find a possibly non-monotonic relationship between the value of office holding and candidate quality. Caselli and Morelli (2003) also investigates the incentives for competent and dishonest individuals to run for office - they make the useful observation, echoed in the model below, that the biggest incentives to seek political office may reside with those who are least fit to hold it. ${ }^{9}$ In common with the analysis below, they show that increasing the rewards to holding political office increases the quality of the political class.

Here, I use a political agency model with moral hazard and adverse selection. Originating with the work of Barro (1973) and Ferejohn

\footnotetext{
${ }^{8}$ This is consistent with the evidence suggesting that electoral success of Governors are not linked to state economic performance.

${ }^{9}$ Ferejohn (1986) also observes that "To the extent that the value of office is determined by the (legal or illegal) behavior of incumbent politicians, that value may tend to be set at a higher level than voters would wish.
} 
(1986), these models treat politicians as agents and elections as means of providing incentives. Politicians have private information and may also have unobserved types. Among the many applications, these models have been used to illuminate the origins of political business cycles (Rogoff 1990), the incentives for government to implement inefficient transfer policies (Coate and Morris 1995), the tax setting behavior of U.S. governors (Besley and Case 1995a,b), and the impact of the separation of powers or other political institutions (Persson, Roland and Tabellini 1997, 2000). Le Borgne and Lockwood (2001) combine a citizen-candidate model with a political agency framework.

The analysis is linked to the argument that certain occupations should be paid efficiency wages. The idea, first formalized by Becker and Stigler (1974), is that higher wages will reduce moral hazard when accompanied by suitable monitoring. Coates (1999) makes this argument explicitly for politicians. ${ }^{10}$ But this view tends to take a homogeneous view of the pool of workers. As argued by Besley and McLaren (1993), when potential workers are heterogeneous, then the case for efficiency wages is weaker since by reducing malfeasance, it can make it difficult to improve the quality of the work force over time. This selection effect makes high wage strategies less attractive. An additional consideration concerns the extent to which the initial pool of applicants for jobs can also be affected by the pay structures put in place.

\section{The Model}

We use a very simple political agency model to consider the effect of varying politicians' wages on policy outcomes. ${ }^{11}$ The model shows how there are three main effects from changing the value of holding political

\footnotetext{
${ }^{10}$ See also, McCormick and Tollinson (1981).

${ }^{11}$ Among existing models, this is closest in spirit to Smart and Sturm (2003a).
} 
office:

- Ex ante selection - wages can affect the kinds of people who choose to enter politics

- Incentives - wages can affect the political behavior of those who are elected

- Ex post-selection - wages can affect the ability of the political process to evaluate the quality of candidates who hold office

Time is infinite and in each period a polity has a series of elections to determine who is to hold office. Denote the election dates as $t=1, \ldots$. Each politician is elected to serve for a maximum of two terms. In each term, he makes a single political decision, denoted by $e_{t} \in\{0,1\}$. The payoff to voters and politicians depends on a state of the world $s_{t} \in\{0,1\}$ which is only observed by the incumbent. Each state occurs with equal probability. Voters receive a payoff $\Delta$ if $e_{t}=s_{t}$ and zero otherwise.

A politician can serve at most two terms. They are two types congruent and dissonant. Let the type be denoted $i \in\{c, d\}$ and let $\pi$ be the probability that a randomly picked politician from the pool is congruent. For the moment we treat this as exogenous. However, we relax this in section 3.2.

The difference between the two types of politicians concerns their willingness to do what voters want. Congruent politicians share voters objectives either through a sense of duty or because their preferences are aligned. Dissonant politicians obtain private benefits from deviating from the voters' preferred policy - they get a private benefit of $r \in[0, R]$ from picking $e_{t} \neq s_{t}$. This benefit is drawn randomly each period according to a (continuous) distribution function $G(r)$. This payoff 
could be derived from the preferences of the politician or from the fact that he is willing to accept bribes from third parties to pick something other than what voters want. The exact interpretation is not important. We denote the realized value by $r_{t}$ and the (time invariant) mean is $\mu$. All politicians (regardless of type) get a payoff $E$ from holding office. We can think of this benefit as comprising any pure ego rents plus any wage from holding office. The variable $E$ could also depend on office perks such as pensions or free housing. It is the variable $E$ that we allow to vary with politicians wages.

With probability $(1-q)$, the dissonant politician is incapable of taking the action which voters like. ${ }^{12}$ For the moment we normalize the politician's outside option to zero. Voters and politicians discount the future with common discount factor $\beta<1$.

Each period nature determines the state of the world and the type of politician if the politician is new. The incumbent politician then picks his preferred action. Voters observe their payoff and decide whether or not to re-elect the incumbent or to return to the pool of potential politicians. Once disposed of, we assume that the politician cannot resume office in the future. Denote the term in office being served by an incumbent by $j \in\{1,2\}$. The action of a politician at time $t$ is denoted by $e_{t}(s, i, j)$ with $s \in\{0,1\}, i \in\{c, d\}$ and $j \in\{1,2\}$.

An equilibrium of the model is a series of actions and voting decisions such that voters use Bayes rule and both voters and politicians optimize. We will focus on equilibria in which the actions of politicians are time invariant, depending only on the state of the world, the type of the politician, and the term that the politician is serving.

\footnotetext{
${ }^{12}$ This assumption is made for convenience so that the kind of equilibrium we study exists for all values of $E>0$. It could be derived equivalently by having a third group of politicians who never do what voters want.
} 


\subsection{Equilibrium Behavior}

Congruent politicians always choose the outcome that voters prefer in both terms in office, i.e. $e(s, c, j)=s$ for $j \in\{1,2\}$. The decision of the dissonant politician is more interesting. In his second term in office, he will always pick his own preferred outcome. Hence $e(s, d, 2)=(1-s)$. His period one decision is more interesting. With probability $(1-q)$ he picks $(1-s)$. With probability $q$, he may choose to do what the voters like. Suppose that by doing so, he will get re-elected. (We will need to check whether this is consistent with voter optimization.) He will weigh the benefit in the form of his personal "rent" $r_{1}$ against the re-election benefit of $\beta[\mu+E]$. Thus, we have

$$
e(s, d, 1)=\left\{\begin{array}{cc}
s & \text { if } r_{1} \leq \beta[\mu+E] \\
(1-s) & \text { otherwise }
\end{array}\right.
$$

Thus, for small enough personal benefits and guaranteed re-election, he is willing to mimic the congruent politician in his first term in office. This is the efficiency wage like property of the model since higher on the job rents can induce politicians to "do the right thing" in the short run. Since the outside option is zero and there is a positive benefit from dissonant behavior, dissonant politicians will only take the voters' preferred action if there is some period two rent from holding political office. Viewed ex ante, the probability that the dissonant politician does what the voters want is $q G(\beta[\mu+E]) \equiv \lambda(E)$, which is increasing in $E$.

We now need to check whether this is consistent with voters behaving optimally. To do so, let $V^{N}(\pi, E)$ be the value to the voter of starting over with a new politician and let $\Pi(\pi, E)$ be the probability that the incumbent is congruent conditional on him generating a benefit of $\Delta$ in his first term. Using Bayes rule, it is straightforward to check that, with 
the equilibrium strategy described above, this is:

$$
\Pi(\pi, E)=\frac{\pi}{\pi+(1-\pi) \lambda(E)} .
$$

Let $\phi(\pi, E)=\pi+(1-\pi) \lambda(E)$ be the probability that a first term incumbent generates the good action for voters. Then, the value of a newly elected politician under this strategy is:

$V^{N}(\pi, E)=\phi(\pi, E)\left[\Delta+\beta \Pi(\pi, E) \Delta+\beta^{2} V^{N}(\pi, E)\right]+(1-\phi(\pi, E)) \beta V^{N}(\pi, E)$.

This has two parts. The first is the case in which the politician in period one does what voters want. In this case he is re-elected for one period after which a new politician comes in. The second term is for the case where the politician does not produce a period one benefit in which case, there is a random selection from the pool. Thus voter welfare viewed from period one is

$V^{N}(\pi, E)=\frac{\Delta}{(1-\beta)} \cdot \frac{\phi(\pi, E)(1+\beta \Pi(\pi, E))}{[1+\beta \phi(\pi, E)]}=\frac{\Delta}{(1-\beta)} \cdot \frac{\phi(\pi, E)+\pi \beta}{[1+\beta \phi(\pi, E)]}$.

This has a nice interpretation. The first term is the discounted value of voter welfare if everyone behaved like congruent politicians. The second term (multiplying this) is less than one and represents the reduction in voter welfare due to the selection and incentive problems in political life.

Using this expression, we now check whether re-electing an incumbent who has produced $\Delta$ is optimal for the voters. This will be true if and only if:

$$
\Pi(\pi, E) \Delta+\beta V^{N}(\pi, E) \geq V^{N}(\pi, E)
$$

which is equivalent to $\Pi(\pi, E) \geq \phi(\pi, E)$ or

$$
\pi \geq(\pi+(1-\pi) \lambda(E))^{2}
$$


Intuitively, this condition says that re-election is worthwhile if and only if the conditional probability that the incumbent will make the right choice for voters exceeds the probability that a new incumbent will. ${ }^{13}$ Putting this together, we now have.

Proposition 1 Suppose that $\pi \geq(\pi+(1-\pi) q)^{2}$, then for all $E \geq 0$, dissonant politicians deliver what voters want in period one with probability $\lambda(E)$ and are re-elected for doing so.

This proposition allows us to generate some predictions about the effect of wages on political behavior. First, consider the impact of wages on the re-election chances of incumbents. It is straightforward to see that re-election is equal to $\phi(\pi, E)$. This is also the probability that the incumbent takes the action that the voter wants.

The effect of raising wages can be decomposed into two parts ex post selection effects and incentive effects. The ex post selection effect depends on the way in which raising politician's wages changes the probability that a politician who produces $\Delta$ is good, i.e. the informativeness of good behavior. This is measured by $\pi / \phi(\pi, E)$ which is decreasing in $E$. Thus having better behaved politicians reduces the chance that any politician who is re-elected is of the congruent type. The incentive effect is measured by $\phi(\pi, E)$ and is increasing in the politician's wage.

Our first prediction from the model is:

Prediction 1: An increase in wages increases the probability of congruence between voter preferences and policy outcomes. As a consequence, it reduces turnover among first period incumbents.

\footnotetext{
${ }^{13}$ I first heard this argument from Michael Smart which appears quite general for the kind of set-up being considered here. Smart and Sturm (2003b) develop this logic further.
} 
Our next result concerns the difference between politicians who are in their first and second term in office. A politician in their second term takes the action that voters prefer with probability $\pi / \phi(E, w)$ while a first term incumbent takes that action with probability $\phi(\pi, E)<$ $\pi / \phi(E, w)$. The difference in these probabilities $[\pi / \phi(E, w)]-\phi(E, w)$ is decreasing in $E$. Thus, we have:

Prediction 2: Conditional on electing a dissonant politician, behavior deteriorates over time. But politicians in their second term in office behave better on average than those in their first term. The difference between second period and first term incumbents is smaller, the larger the politician's wage.

Now we turn to optimal wage setting. Obviously there is a cost to paying politicians more in the form of higher taxes needed to finance wage payments. In general, we would expect two kinds of effects from raising wages - selection effects and incentive effects (see Besley and Smart (2003)). By raising wages, incumbents are more likely to do what voters want. However, this leads to less information being revealed in equilibrium since more dissonant incumbents are elected to a second term in office. These effects tend to make many comparative statics results in this class of models ambiguous. However, in this model, the ambiguity is resolved in the direction of dominant incentive effects. ${ }^{14}$ Thus, we have:

Prediction 3: Increasing the value of holding office raises voter welfare.

This is not obvious. ${ }^{15}$ The incentive effect raises welfare in proportion

\footnotetext{
${ }^{14}$ See Besley (2003, chapter 3) for further discussion.

${ }^{15}$ While this paralells the more standard "efficiency wage" logic of Ferejohn (1986, Proposition 5), he has a model with homogeneous politicians.
} 
to $\Delta$ in the first term in office. However, the selection effect reduces term two welfare and is of order $-\beta \frac{\pi}{\phi} \times \Delta .{ }^{16}$ The former dominates the latter since $\beta \frac{\pi}{\phi}<1$. We will assess the robustness of this finding below.

In general, we would expect optimal wages from the voter's point of view to solve:

$$
E=\arg \max \left\{V^{N}(\pi, E)-C(E)\right\}
$$

where $C(E)$ denotes the cost of raising tax revenue. The optimal wage trades off the marginal cost of public resources against the marginal benefits in improved politician behavior.

\subsection{Standing for Political Office}

In his classic book on voting, V.O. Key quips "If the people can choose only from among rascals, they are certain to choose a rascal." Key (1966, page 7)). To understand whether the pool contains only "rascals" requires a model in which the pool of candidates for office is endogenous. Here, we specifically want to investigate the argument that paying politicians more will lead "better people" to enter politics. When competence is at stake, this seems clear. ${ }^{17}$ However, whether it is easier to attract those who are more likely to place a greater weight on the interests of voters is less clear cut.

In this section, we explore these ideas by making the pool of people presenting themselves for political office endogenous. What matters here is not that increasing wages attracts more people to politics, but how the different types of politicians are differentially attracted by wage increases. Is it the case that congruent or dissonant politicians are relatively more likely to enter as wages increase?

\footnotetext{
${ }^{16}$ There is also a non-negative term due to the fact that along the equilibrium path, the value of a retained incumbent is weakly higher than that of a new incumbent.

${ }^{17}$ Although see section four for a caveat to this.
} 
Here, we look at this issue very crudely - the winning politician is a random selection from among those willing to serve. This abstracts from many institutions that affect candidate selection such as campaigning, party selection and voting. ${ }^{18}$ We suppose that there is a continuum of potential politicians with outside per period wages $w \in\left[0, W^{i}\right]$ with $i \in\{c, d\}$. We assume that this is uniformly distributed, with the distributions differing for the two groups of politicians. Suppose that the probability that a candidate is of the congruent type in the entire pool of possible politicians is $\gamma$.

For congruent politicians, recruitment implies retention. A politician will stay in office for a second term if $E \geq w$. Since he is re-elected for sure, he will also enter in period one if $E \geq w \cdot{ }^{19}$ Thus, the fraction of congruent citizens who will be willing to enter politics is $\frac{E}{W^{c}}$.

We now turn to the dissonant citizens and their decision to run as candidates. Adding in the outside option will now lead to a slight modification of the model above as the optimal action of dissonant politicians now depends upon their private sector wage rate. Specifically,

$$
e(s, d, 1, w)=\left\{\begin{array}{cc}
s & \text { if } r_{1} \leq \beta([\mu+E]-w) \\
(1-s) & \text { otherwise }
\end{array}\right.
$$

Thus, politicians with more generous outside opportunities are less likely to take the congruent action. This is because their rent from holding political office compared to the private sector is smaller. Let $\bar{w}$ be the maximal private sector wage that a dissonant politician will forego in order to become a politician. Then the probability of congruent behavior by a randomly selected dissonant politician who is willing to

\footnotetext{
${ }^{18}$ See Besley (2003, chapter 6) for a preliminary effort in this direction.

${ }^{19}$ Two interesting possibilities are seniority premia for being in office (in the private sector) and a risk on not being re-elected in which case retention can be a problem.
} 
serve is now

$$
\Lambda(E, \bar{w})=\int_{0}^{\bar{w}} G(\beta([E+\mu]-w)) \frac{d w}{\bar{w}} .
$$

Dissonant politicians are willing to serve if they are re-elected if $\mu+E \geq$ $w$. We now look at recruitment on the assumption that this holds. If a politician stays in the private sector, he will make a stream of utility $v(w)=\frac{w}{(1-\beta)}$. Then, the value from entering politics when the private sector option is $w$ is:

$$
\begin{array}{rl}
P(E+\mu, w) 1 \mathrm{pt}= & 1 \mathrm{pt} E+\left(\int_{\beta[(E+\mu)-w]}^{R}(r+\beta v(w)) d G(r)\right) \\
1 \mathrm{pt} & 1 \mathrm{pt}+G(\beta[E+\mu]-w)\left(\beta(\mu+E)+\beta^{2} v(w)\right) .
\end{array}
$$

The dissonant politicians who participate in politics are those for which $v(w) \leq P(w)$. Solving this yields:

$$
w \leq(E+\mu)+\psi(E+\mu-w)
$$

where $\psi(x)=\frac{-\int_{0}^{\beta x} r d G(r)}{1+G(\beta x) \beta}<0$ and $\psi^{\prime}(x)<0$. The last term on the right hand side of this expression is the expected forgone rent (i.e. below $\mu$ ) due to behaving well in the first period. Thus, the critical wage below which dissonant politicians will put themselves forward for office is defined by

$$
\bar{w}(E, \mu) \equiv(E+\mu)+\psi(E+\mu-\bar{w}((E, \mu))) .
$$

We assume that there is a unique solution to this equation. ${ }^{20}$ It is clear that $\bar{w}(E, \mu)<E+\mu$. Hence, consistent with what we assumed above,

\footnotetext{
${ }^{20}$ The possibility of multiple equilibria is intriguiging. The mechanism is as follows. There can be a high reservation wage option where a significant fraction of dissonant politicians enter and expected rents are high since these politicians are less likely to be tempted to pick the congruent action. In the low reservation wage equilibrium, expected rents are relatively low as dissonant politicians who enter are more likely to pick the dissonant action.
} 
dissonant politicians who are willing to enter are also willing to serve a second term if they are re-elected. This implies that the fraction of dissonant politicians who are willing to become politicians is:

$$
\frac{\bar{w}(E, \mu)}{W_{d}}
$$

Using this, the fraction of congruent politicians in the pool of candidates available for public office is:

$$
\pi(E)=\frac{\gamma}{\gamma+(1-\gamma)\left[\frac{\bar{w}(E, \mu)}{E} \cdot \frac{W_{c}}{W_{d}}\right]}
$$

This depends upon the relative returns to politics of dissonant and congruent types and their relative private sector options. We now have:

Proposition 2 The quality of the politicians in the pool is higher if wages are higher.

The rents earned by dissonant politicians make them more eager to enter politics than congruent ones and raising wages redresses the balance. Thus, the model predicts that, in addition to incentive effects, raising wages improves the pool of politicians who are willing to serve. The size of this effect depends on the ratio $(1-\gamma) / \gamma$. Thus, the effect is larger if there is a relative dearth of congruent individuals.

This discussion leads to the following:

Prediction 4: Paying higher wages will tend to increase the fraction of congruent politicians who will put themselves forward for office.

This prediction underpins the idea that we should find that the characteristics of politicians should vary systematically with the wages that are paid. Higher paying polities should have more individuals with "desirable" characteristics standing. 


\section{Discussion}

Recent empirical work by Diermeier, Keane and Merlo (2002) suggests that serving as a politician may boost private sector earnings after leaving office. ${ }^{21}$ How this finding affects incentives, selection and turnover depends on exactly how this premium accrues. If rewards are purely for having served, regardless of performance while in office, then this will affect the decision to come forward for elective office while leaving performance in office unaffected.

If private sector rewards accrue disproportionately to those who have been re-elected, say because congruent types are more valuable than dissonant types in the private sector, then returns to public office that accrue in the private sector will affect equilibrium behavior. In particular, higher rewards will increase congruent behavior by dissonant politicians. It could even induce such behavior even when a politician faces a term limit. Overall, this is beneficial to voters. There would be a similar effect from allowing politicians to run for further political office where a past record of doing what voters want is valuable.

A downside from post office rewards would arise if dissonant behavior were rewarded disproportionately in the private sector. For example a politician who gives in to a special interest while in office may earn an even larger reward upon leaving office. This will reduce congruence although selection will play a key role. Public shows of dissonance that earned rents would also lead to larger numbers of such individuals opting for a career in public life, worsening the pool of potential politicians.

\footnotetext{
${ }^{21}$ Their data source is the U.S. Congress. Specifically, they find that congressional experience increases wages in post-congressional occupations. They also estimate a large non-pucuniary reward from holding a congressional seat suggesting that $E$ in our model will likely contain things other than monetary factors.
} 
The model has focused exclusively on differences between politicians in terms of their willingness to act in voters' interests. Another general concern with politics is the competence level of politicians. We could intrdouce such concerns by assuming that the private sector wage $w$ is a measure of competence and that there is a benefit to having a competent office holder related to $w$. In this case, the voters would care about the average value of $w$ in the population of potential politicians. The expected competence level among politicians is:

$$
\frac{\gamma \frac{E}{W^{c}} \cdot \frac{E}{2}+(1-\gamma) \frac{\bar{w}(E+\mu)}{W^{d}} \cdot \frac{\bar{w}(E+\mu)}{2}}{\gamma \frac{E}{W^{c}}+(1-\gamma) \frac{\bar{w}(E+\mu)}{W^{d}}} .
$$

Surprisingly, this is not necessarily increasing in $E$. There are two competing effects. While the quality of participants from each group improves as $E$ increases, the weights also change. Specifically, increasing $E$ induces entry by the relatively less competent congruent group. ${ }^{22}$ For small $\gamma$ the first effect dominates and average competence increases.

We have not allowed congruent politicians to receive any direct utility from helping voters. As we noted in the introduction, this kind of public service motivation is frequently appealed to in political life. In this model, it would mainly affect the set of individuals who chose to put themselves forward, increasing the fraction of congruent politicians. If public service motivation were high enough (essentially a stronger pull into public life than rents earned by the dissonant politicians), then the prediction on the effect of wages on the pool of politicians would be overturned - raising wages would attract more dissonant relative to congruent politicians. Indeed in such a world, there could be a case for amateur politicians, i.e. making $E$ as small possible.

It is also possible to question the proposition that raising wages actually improves the behavior of politicians. This is explored in Smart

\footnotetext{
${ }^{22} \mathrm{I}$ am grateful to Rocco Macchiavello for the correct analysis of this point.
} 
and Sturm (2003c). For this to be a possibility, however, it must be the case that political equilibria distort the behavior of congruent politicians away from doing what voters want. This cannot happen in the current set-up, but a variant of this model can capture this idea. Suppose that the dissonant politician has a bias towards one of the actions and voters observe the payoff from the actions taken only after the next election. In this case, congruent politicians may choose the action which is against the bias of dissonant politicians in order to get re-elected. Their incentive to do so is greatest when holding office is most valuable, i.e. wages are high. Thus increasing wages could actually reduce congruence. ${ }^{23}$

Our model of selection into the pool has focused exclusively on incentives to become a politician and not on the active politics of candidate selection. This is explored further in Besley (2003, chapter 6). ${ }^{24}$ There are two main reasons why the best politicians from any self-selected group may not be chosen for office - the fact that voters cannot coordinate their actions to vote collectively for the highest quality candidates, as in Besley and Coate (1997), and the possibility that parties do not have the best incentives to run congruent candidates. This might be true if the rents earned by congruent candidates were shared among the party elite. If either of these forces are responsible for keeping candidate quality low, then there is no reason to expect wages to have a favorable effect on the quality of candidates who are put forward from among those who are willing to stand.

\footnotetext{
${ }^{23}$ This is what Smart and Sturm (2003a) call a timid equilibrium and is related to the notion of pandering suggested by Maskin and Tirole (2000).

${ }^{24}$ See also Carrillo and Mariotti (2001) for a model of candidate selection by political parties.
} 


\section{A Brief Look at Some Evidence}

Although comprehensive testing lies beyond this lecture, it will help to breath life into the ideas if we look briefly at some evidence. One nice feature of the political agency model is its ability to make quite specific predictions about how wages affect outcomes. However, political situations rarely meet the rather stark institutional setting of such models. Notably absent from the models are long-lived institutions such as political parties and other systems of checks and balances that are characteristic of most systems of government. The models are most promising when applied in situations where there are directly elected chief executives with significant discretionary power. U.S. Governors are certainly a promising setting as they do fit the basic theoretical structure fairly well. $^{25}$

Another significant advantage with the study of Governors is the plentiful supply of data. ${ }^{26}$ In line with the theory, we will focus on those states in the U.S. that impose a term limit on their Governors. Leaving out Virginia which has a one term limit, this leaves a sample of eighteen states. ${ }^{27}$ Table 2 gives the means of the main variables used in the analysis.

As we discussed above, there is significant wage variation in the salaries of U.S. Governors. ${ }^{28}$ In 1982 dollars, the median annual salary

\footnotetext{
${ }^{25}$ For this reason, Besley and Case $(1995 \mathrm{a}, \mathrm{b})$ both test ideas from the political agency literature on U.S. governors.

${ }^{26}$ Much of the data used were collected for the project in Besley and Case (2003).

${ }^{27}$ See Besley and Case (1995b) for background discussion of term limits for U.S. Governors.

${ }^{28}$ Data on Governors salaries is available fairly straightforwardly. This contrasts with data on legislators where it is extremely difficult to get any kind fo reasonably comparable measure. For example, legislatures differ considerably in the time commitment that they require. However, it is hard to get data on perks and other
} 
is around $\$ 60,000 .^{29}$ Wages are significantly higher in states that have higher incomes per capita. In the sample of states used to produce Table 3 below, the elasticity of the wage with respect to state income per capita is 0.8 . More populous states appear to pay lower wages - with an elasticity with respect to the wage of -0.54 . There is also evidence of a negative correlation between wages are the length of term served by the Governor. There is no significant relationship between wages and the size of government.

Our main empirical evidence comes from a direct test of whether congruence between the Governor and the citizens is higher when states pay higher wages. To do this, we use a measure of congruence between the ideological positions of the governor and the citizens using data constructed by Berry et al (1998). Our measure of congruence is minus the absolute difference between the estimated governor and citizen ideology in state $i$ at time $t$. Berry et al (1998) provide two measures of this, one based on scores from Americans for Democratic Action (ADA) rating system and the other from ratings of the AFL/CIO's Committee on Political Education (COPE). These data are available for the period 1960-93.

Our theoretical model predicts greater congruence between governor and citizen ideology if wages are higher - this could be because of either selection or incentive effects. We would also expect governor's in their second period in office to be more congruent - since they have been reelected. Finally, we would expect a negative interaction term between features of remuneration which could be important. Most Governors, for example, receive a house and this may vary considerably in quality. The look at the data is sketchy and exploratory. I am grateful to Ray Fisman for providing me with the data.

${ }^{29}$ The wage data come from DiTella and Fisman (2001). 
these two variables, i.e., a smaller term limit effect in states that pay higher wages.

The specification that we run is:

$$
c_{i t}=\alpha_{i}+\beta_{t}+\theta w_{i t}+\gamma r_{i t}+\rho\left(w_{i t} * r_{i t}\right)+\chi y_{i t}+\varepsilon_{i t}
$$

where $c_{i t}$ is the congruence measure, $\alpha_{i}$ is a state fixed effect, $\beta_{t}$ is a year fixed effect, $r_{i t}$ is a dummy variable which equals one in all years in which the governor cannot run for re-election, $w_{i t}$ is a dummy variable which equals one when the governor is paid above the median governor's wage for the whole sample, $y_{i t}$ represents other exogenous variables and $\varepsilon_{i t}$ is the error. In estimating (1) we allow for robust standard errors. Our exogenous variables include both basic state economic and demographic controls - the log of real income per capita, the log of state population, the population aged over 65 and aged 5-17. We also include various political controls - the party of the governor, who controls the legislature, and whether there is divided control of the governor's chair and the legislature.

The results are presented for both congruence measures in Table 3. The first and third columns do not include the interaction between wages and term limit - this term appears in the specification of columns (2) and (4). All four columns of the table suggest that states that paying higher wages leads to more congruent Governors. Also in line with the model, Governors who are term limited are more congruent. This is consistent with the importance of the selection effect in elections. The results on the interaction terms are not so encouraging to the theory - in neither case do we see the predicted negative interaction effect. Among the other coefficients, note that the political controls are always significant with Democratic governors being more congruent while Democratic legislatures reduced congruence. Divided government also leads to less 
congruent outcomes.

These reduced form findings are consistent with either a selection or incentive effect. To see whether wages affect observable characteristics of successful candidates, we correlated various Governors characteristics with the high wage variable. There is a positive and significant correlation between the high wage states and the governor being a lawyer. There is also a positive correlation with years of political experience and (relatedly) the age of the governor. This merits a more detailed investigation - ideally we would look at characteristics of candidates rather than elected politicians.

The evidence is crude. However, there is sufficient encouragement here to suggest the need for a more detailed investigation. One major challenge for future research is to find ways of treating wages as endogenous while studying political accountability.

\section{Concluding Comments}

This lecture has suggested an organizing framework for thinking about how the remuneration of politicians affects their behavior and the pool of politicians. The theoretical building block has been a political agency model with term-limited politicians. While this is a rather special context, some clean insights were generated. The centre-piece of the behavioral predictions concerned how wages would affect the use of elections as accountability mechanisms. We also modified the approach to think about the likely pool of politicians that will put themselves forward for election.

Our testing ground for these ideas was U.S. Governors. They are ideally suited for the model given that they are individually accountable and the richness of the data available. The empirical results are weakly 
encouraging to the view that pay rates of politicians affect behavior of this sample of politicians either by changing incentives or by altering the pool of politicians who put themselves forward for office. However, it is clear that the present exercise is only a first pass and much more needs to be done to produce a definitive account.

In thinking about what makes office holding valuable, wages may not be of first order importance. Indeed, they could be a fairly small part of what motivates politicians to enter and to act in the voters' interest. Hence, it does seem important to look at the wider factors that make political life attractive. In understanding how electoral mechanisms achieve accountability, it is likely that the selection and incentives of politicians depend importantly on the costs and benefits of public life.

More generally, studying what goes into the making of a political class has received comparatively little attention relative to the staple public choice concern of keeping wayward politicians honest. The study of models with heterogeneous types opens up a rich vein of possibilities for both theoretical and empirical research in political economy. 


\section{References}

Barro, Robert, [1973], "The Control of Politicians: An Economic Model," Public Choice, 14, pp. 19-42.

Becker, Gary S. and George J. Stigler, [1974], "Law Enforcement, Malfeasance and Compensation of Enforcers," Journal of Legal Studies, 3(1), pp. 1-18.

Berry, William D., Evan J. Ringquist, Richard C. Fording and Russell Hanson, [1998], "Measuring Citizen and Government Ideology in the American States, 1960-93," American Journal of Political Science, 42(1), pp. 327-348.

Besley, Timothy, [2003], Principled Agents? Motivation and Incentives in Government, The Lindahl Lectures 2002, forthcoming from Oxford University Press.

Besley, Timothy and Anne Case, [1995a], "Incumbent Behavior: Vote Seeking, Tax Setting and Yardstick Competition", American Economic Review 85(1), pp. 25-45.

Besley, Timothy and Anne Case, [1995b], "Does Political Accountability Affect Economic Policy Choices? Evidence From Gubernatorial Term Limits, Quarterly Journal of Economics 110(3), pp. 769-98.

Besley, Timothy and Anne Case, [2003], "Political Institutions and Policy Choices: Evidence from the United States," Journal of Economic Literature, 41(1), pp. 7-73.

Besley, Timothy and Stephen Coate, [1997], "An Economic Model of Representative Democracy," Quarterly Journal of Economics, 112(1), pp. $85-114$.

Besley, Timothy and Maitreesh Ghatak, [2003], "Competition and Incentives with Motivated Agents," mimeo, London School of Economics.

Besley, Timothy and Michael Smart, [2003], "Fiscal restraints and 
voter welfare" mimeo, London School of Economics.

Besley, Timothy and John McLaren, [1993], "Taxes and Bribery: The Role of Wage Incentives" Economic Journal, 103(416), pp. 119-41

Buchanan, James, [1989], "The Public Choice Approach," in Essays on Political Economy, Honolulu : University of Hawaii Press.

Carillo, Juan and Thomas Marriotti, [2000], "Electoral Competition and Politician Turnover ", European Economic Review, 45(1), pp. 1-26.

Caselli, Francesco and Massimo Morelli, [2003], "Bad Politicians," Journal of Public Economics, forthcoming.

Coate, Stephen and Stephen Morris, "On the form of transfers to special interests," Journal of Political Economy, 103, pp. 1210-35.

Coates, Dennis, [1999], "Efficiency Wages for Politicians: Do Better Paid Officials Produce Better Outcomes," typescript available at http://research.umbc.edu/\%7Ecoates/work/salaryre.pdf

Diermeier, Daniel, Michael Keane and Antonio Merlo, [2002], "A Political Economy Model of Congressional Careers," mimeo, University of Pennsylvania.

Dixit, Avinash, [1996], The Making of Economic Policy: ATransactionsCost Politics Perspective, Cambridge: MIT Press.

Dixit, Avinash [2002]: Incentives and Organizations in the Public Sector: An Interpretive Review, Journal of Human Resources, Fall 2002, 37(4), pp. 696-727.

Ferejohn, John, [1986], "Incumbent Performance and Electoral Control," Public Choice, 50, pp. 5-25.

Fisman, Ray and Rafael DiTella, [2001], "Are Politicians Really Paid Like Bureaucrats?" typescript.

Frey, Bruno S., [1997], Not Just for the Money: An Economic Theory of Personal Motivation, Cheltenham: Edward Elgar Publishing. 
Holmstrom, Bengt, [1999], "Managerial Incentive Problems: A Dynamic Perspective," Review of Economic Studies, 66(1), pp. 169-82.

Holmstrom, Bengt, and Paul Milgrom [1991]: Multi-task PrincipalAgent Analysis: Incentive Contracts, Asset Ownership, and Job Design" Journal of Law, Economics and Organization, 7 (Special Issue), 24-52.

Key, V.O., [1956], American State Politics: An Introduction, New York, NY: Alfred A. Knopf.

Key, V.O., [1966], The Responsible Electorate: Rationality in Presidential Voting: 1936-60, Cambridge MA: Belknap Press.

Lazear, Edward and Sherwin Rosen, [1980], "The Economics of Compensation of Government Officials," in Robert W. Hartman and Arnold Weber, The Rewards of Public Service: Compensating Top Federal Officials, Washington DC: Brookings.

Le Borgne, Eric and Ben Lockwood, [2001a], "Do Elections Always Motivate Incumbents?" Warwick Economic Research Paper No. 580.

List, John and Daniel Sturm, [2001], "Politics and Environmental Policy: Theory and Evidence from U.S. States," unpublished typescript: University of Maryland and University of Munich.

McCormick, Robert E. and Robert D. Tollinson, [1981], Politicians, Legislation and the Economy: An Inquiry into the Interest-Group Theory of Government, Boston MA: Martinus Nijhoff.

Maskin, Eric and Jean Tirole, [2000], "The Politician and the Judge," unpublished typescript.

Messner, Matthias and Mattias K. Polborn, [2001], "Paying Politicians," typescript.

Osborne, Martin J. and Al Slivinski, [1996], "A Model of Political Competition with Citizen Candidates," Quarterly Journal of Economics, 111(1), pp. 65-96. 
Persson, Torsten, Gerard Roland and Guido Tabellini, [1997], "Separation of Powers and Political Accountability," Quarterly Journal of Economics, 112(4), pp. 1163-1202.

Persson, Torsten, Gerard Roland and Guido Tabellini, [2000], "Politics and Public Finance," Journal of Political Economy, 108(6), pp. $1121-1161$.

Poutvaara, Panu and Tuomas Takalo, [2003], "Candidate Quality," unpublished typescript.

Rogoff, Kenneth, [1990], "Equilibrium Political Budget Cycles," American Economic Review, 80(1), pp. 21-36.

Smart, Michael and Daniel Sturm, [2003a], "Term Limits and Electoral Accountability," typescript.

Smart, Michael and Daniel Sturm, [2003b], "Does Democracy Work? Estimating Incentive and Selection Effects of U.S. Gubernatorial Elections, 1950-2000", unpublished notes.

Smart, Michael and Daniel Sturm, [2003c], "Paying Politicians: Is More Always Better?", typescript.

Sollars, David L., [1994], "Institutional Rules and State Legislator Compensation: Success for the Reform Movement?," Legislative Studies Quarterly, 19 (4), pp. 507-520.

Squire, Peverill, [1992], "Legislative Professionalization and Membership Diversity in State Legislatures," Legislative Studies Quarterly, 17 (1), pp. 69-79. 
Table 1: Political Chief Executives in Four Countries

\begin{tabular}{ccccc}
\hline & France & Sweden & $\begin{array}{c}\text { United } \\
\text { Kingdom }\end{array}$ & United States \\
\hline President or Prime Minister's Salary & $\$ 80,000$ & $\$ 130,000$ & $\$ 270,000$ & $\$ 400,000$ \\
Salary/GDP per capita & 3.05 & 5.11 & 10.60 & 11.02 \\
& & & & \\
Salary(000s) per Billion Dollars of & 0.33 & 1.18 & 0.50 & \\
Government Expenditures & & & & \\
& & & & \\
& & & & \\
& & & & \\
\hline
\end{tabular}

Notes: Sources Congressional quarterly, www.cabinet-office.gov.uk, www.sweden.gov.se, www.telegraph.co.uk (France), CIA fact book, OECD plus author's calculations. 


\begin{tabular}{lcc} 
& Mean & Standard Deviation \\
\hline $\begin{array}{l}\text { Governor's wage }(\$ 1982) \\
\text { (all } 48 \text { continental states, }\end{array}$ & 63224.15 & 18735.64 \\
$\begin{array}{l}\text { 1950-2000) } \\
\text { Governor is paid above } \\
\text { median wage }\end{array}$ & 0.69 & 0.46 \\
$\begin{array}{l}\text { Governor faces binding term } \\
\text { limit }\end{array}$ & 0.56 & 0.50 \\
$\begin{array}{l}\text { Governor is a Democrat } \\
\begin{array}{l}\text { Democrats control both } \\
\text { houses }\end{array}\end{array}$ & 0.67 & 0.47 \\
$\begin{array}{l}\text { Divided Government } \\
\text { Log of real income per capita } \\
\text { (\$1982) }\end{array}$ & 0.82 & 0.38 \\
$\begin{array}{l}\text { Log of state population } \\
\% \text { population aged 65 and }\end{array}$ & 0.29 & 0.45 \\
$\begin{array}{l}\text { above } \\
\text { below }\end{array}$ & 16.90 & 1.15 \\
Congruence (COPE) & 15.08 & 0.71 \\
Congruence (ADA) & 0.11 & 0.24 \\
\hline & 0.23 & 0.04 \\
\hline
\end{tabular}

Notes: Sample (except where stated) is for the years 1960-93 for the eighteen states that had term-limits over the whole period (excluding Virginia). 
Table 3. Congruence

\begin{tabular}{|c|c|c|c|c|}
\hline (1) & (2) & (3) & (4) & \\
\hline & $\begin{array}{l}\text { Congruence } \\
\text { (COPE) }\end{array}$ & $\begin{array}{l}\text { Congruence } \\
\text { (COPE) }\end{array}$ & $\begin{array}{l}\text { Congruence } \\
\text { (ADA) }\end{array}$ & $\begin{array}{l}\text { Congruence } \\
\text { (ADA) }\end{array}$ \\
\hline $\begin{array}{l}\text { Governor is paid } \\
\text { above median } \\
\text { wage }\end{array}$ & $\begin{array}{l}2.489 \\
(3.63)^{* *}\end{array}$ & $\begin{array}{l}2.711 \\
(2.68)^{* *}\end{array}$ & $\begin{array}{l}2.189 \\
(3.59)^{* *}\end{array}$ & $\begin{array}{l}1.738 \\
(1.90)\end{array}$ \\
\hline $\begin{array}{l}\text { Governor faces } \\
\text { binding term limit }\end{array}$ & $\begin{array}{l}1.995 \\
(3.07)^{* *}\end{array}$ & $\begin{array}{l}2.282 \\
(1.89)\end{array}$ & $\begin{array}{l}0.842 \\
(1.54)\end{array}$ & $\begin{array}{l}0.258 \\
(0.24)\end{array}$ \\
\hline $\begin{array}{l}\text { Governor is paid } \\
\text { above median } \\
\text { wage * binding } \\
\text { term limit }\end{array}$ & & $\begin{array}{l}-0.383 \\
(0.30)\end{array}$ & & $\begin{array}{l}0.779 \\
(0.68)\end{array}$ \\
\hline $\begin{array}{l}\text { Governor is a } \\
\text { Democrat }\end{array}$ & $\begin{array}{l}3.855 \\
(4.70) * *\end{array}$ & $\begin{array}{l}3.842 \\
(4.69) * *\end{array}$ & $\begin{array}{l}3.597 \\
(5.51) * *\end{array}$ & $\begin{array}{l}3.624 \\
(5.59) * *\end{array}$ \\
\hline $\begin{array}{l}\text { Democrats control } \\
\text { both houses }\end{array}$ & $\begin{array}{l}-3.735 \\
(3.46)^{* *}\end{array}$ & $\begin{array}{l}-3.705 \\
(3.41)^{* *}\end{array}$ & $\begin{array}{l}-1.323 \\
(1.36)\end{array}$ & $\begin{array}{l}-1.383 \\
(1.42)\end{array}$ \\
\hline $\begin{array}{l}\text { Divided } \\
\text { Government }\end{array}$ & $\begin{array}{l}-3.043 \\
(3.73)^{* *}\end{array}$ & $\begin{array}{l}-3.039 \\
(3.72)^{* *}\end{array}$ & $\begin{array}{l}-1.920 \\
(2.90) * *\end{array}$ & $\begin{array}{l}-1.929 \\
(2.91)^{* *}\end{array}$ \\
\hline $\begin{array}{l}\text { log of real income } \\
\text { per capita }(\$ 1982)\end{array}$ & $\begin{array}{l}-24.452 \\
(3.30)^{* *}\end{array}$ & $\begin{array}{l}-24.249 \\
(3.24)^{* * *}\end{array}$ & $\begin{array}{l}-33.170 \\
(4.82)^{* *}\end{array}$ & $\begin{array}{l}-33.582 \\
(4.85)^{* *}\end{array}$ \\
\hline $\begin{array}{l}\text { log of state } \\
\text { population }\end{array}$ & $\begin{array}{l}11.327 \\
(1.30)\end{array}$ & $\begin{array}{l}10.968 \\
(1.24)\end{array}$ & $\begin{array}{l}12.829 \\
(1.55)\end{array}$ & $\begin{array}{l}13.561 \\
(1.61)\end{array}$ \\
\hline $\begin{array}{l}\% \text { population aged } \\
65 \text { and above }\end{array}$ & $\begin{array}{l}-35.423 \\
(0.69)\end{array}$ & $\begin{array}{l}-35.919 \\
(0.70)\end{array}$ & $\begin{array}{l}37.991 \\
(0.84)\end{array}$ & $\begin{array}{l}39.000 \\
(0.86)\end{array}$ \\
\hline $\begin{array}{l}\% \text { population aged } \\
17 \text { and below }\end{array}$ & $\begin{array}{l}102.322 \\
(1.80)\end{array}$ & $\begin{array}{l}103.404 \\
(1.82)\end{array}$ & $\begin{array}{l}43.576 \\
(0.89) \\
\end{array}$ & $\begin{array}{l}41.374 \\
(0.83)\end{array}$ \\
\hline State fixed effects & Yes & Yes & Yes & Yes \\
\hline Year fixed effects & Yes & Yes & Yes & Yes \\
\hline Observations & 612 & 612 & 612 & 612 \\
\hline R-squared & 0.68 & 0.68 & 0.76 & 0.76 \\
\hline
\end{tabular}

Notes: Robust t statistics in parentheses (* significant at 5\%; ** significant at $1 \%$ ). The results use data for the eighteen states that always had term limits in the period 1960-93 (excluding Virginia which has a one-term limit). The congruence measure is taken from Berry et al (1997). It is minus the absolute difference between the ADA/COPE scores of the citizens and the Governor in each state for each year. Governor's wage data were supplied by Ray Fisman and are documented in DiTella and Fisman (2002). The variable used is a dummy variable equal to one if the state pays the Governor more than $\$ 60,000$ in real 1982 dollars. Divided Government is a dummy variable which equals one if the Governor's chair and the legislature are controlled by different parties. For sources of economic and demographic data, see Besley and Case (2003). 